Geosistemy perehodnykh zon = Geosystems of Transition Zones / Геосистемы переходных зон

Content is available under the Creative Commons Attribution 4.0 International License (CC BY 4.0)

2021, vol. 5, No. 3, pp. 229-239

URL: http://journal.imgg.ru/archive.html ; https://elibrary.ru/title about.asp?id=64191

https://doi.org/10.30730/gtrz.2021.5.3.229-239

\title{
Peculiarities of anomalous gas-geochemical fields \\ in the East Deryugin graben of the Sea of Okhotsk
}

Renat Belalovich Shakirov' (https://orcid.org/0000-0003-1202-0351), ren@poi.dvo.ru

Anna Leonidovna Venikova1 (https://orcid.org/0000-0002-1445-8579), anett29@mail.ru

Natalia Leonidovna Sokolova1 (https://orcid.org/0000-0002-2248-6924), natap81@mail.ru

Anatolii Ivanovich Obzhirov ${ }^{1}$ (https://orcid.org/0000-0002-4031-6419), obzhirov@poi.dvo.ru

Oleg Vasil'evich Veselov² (https://orcid.org/0000-0003-3151-324X), o.veselov@imgg.ru

Elena Valer'evna Maltceva1 (https://orcid.org/0000-0003-3230-7042), ekor@poi.dvo.ru

Fedor Vladimirovich Kuziv ${ }^{3}$ (https://orcid.org/0000-0002-0307-0552), frostimus@gmail.com

Vasilii Konstantinovich Leksin ${ }^{4}$ (https://orcid.org/0000-0003-2635-9882), lex-vasya@mail.ru

IV.I. Il'ichev Pacific Oceanological Institute, FEB RAS, Vladivostok, Russia

2Institute of Marine Geology and Geophysics, FEB RAS, Yuzhno-Sakhalinsk, Russia

3LLC FGTC Technology, Saint-Petersburg, Russia

${ }_{4}^{4 R N-S a k h a l i n N I P I m o r n e f t » ~ L L C, ~ Y u z h n o-S a k h a l i n s k ~}$

\section{Abstract PDF ENG Резюме PDF RUS $\quad$ Full text $\underline{\text { PDF RUS }}$}

Abstract. This paper presents the research data on methane distribution in the area of the most noticeable gas discharges in the Deryugin Basin of the Sea of Okhotsk. In the East Deryugin graben, a unique methane seep is known, which spatially coincides with the local authigenic barite-carbonate mineralization. The question of the source nature, which is associated with the methane emission in the studied area, is considered.

\section{Keywords:}

\section{methane, gas hydrates, authigenic barite mineralization, anomalous methane fields, Deryugin basin, the Sea of Okhotsk}

For citation: Shakirov R.B., Venikova A.L., Sokolova N.L., Obzhirov A.I., Veselov O.V., Maltceva E.V., Kuziv F.V., Leksin V.K. Peculiarities of anomalous gas-geochemical fields in the East Deryugin graben of the Sea of Okhotsk. Geosistemy perehodnykh zon $=$ Geosystems of Transition Zones, 2021, vol. 5, no. 3, pp. 229-239. (In Russ., abstr. in Engl.). https://doi.org/10.30730/gtrz.2021.5.3.229-239

Для цитирования: Шакиров Р.Б., Веникова А.Л., Соколова Н.Л., Обжиров А.И., Веселов О.В., Мальцева Е.В., Кузив Ф.В., Лексин В.К. Особенности аномальных газогеохимических полей в Восточно-Дерюгинском грабене Охотского моря. Геосистемы переходных зон, 2021, т. 5, № 3, c. 229-239. https://doi.org/10.30730/gtrz.2021.5.3.229-239

\section{References}

1. Astakhova N.V., Lipkina M.I., Mel'nichenko Yu.I. 1987. [Hydrothermal barite mineralization in the Deryugin basin of the Sea of Okhotsk]. Doklady AN SSSR, 295: 242-245. (In Russ.).

2. Astakhova N.V., Narnov G.A., Yakusheva I.N. 1990. [Carbonate-barite mineralization in the Deryugin basin (the Sea of Okhotsk)]. Geology of the Pacific Ocean, 3: 37-42. (In Russ.).

3. Akhmanov G.G., Egorova I.P., Mikhaylik P.E., Grevtsev V.A., Naumkina N.I., Semenova G.M. 2015. [To a genesis of travertine-like barites from the Deryugin basin (the Sea of Okhotsk)]. Otechestvennaya geologiya, 1: 82-87. (In Russ.).

4. Veselov O.V., Semakin V.P., Kochergin A.V. Heat flow and neotectonics of the Deryugin Basin (Okhotsk Sea). Geosistemy perehodnykh zon = Geosystems of Transition Zones, 2(4): 312-322. doi.org/10.30730/2541-8912.2018.2.4.312-322 (In Russ.).

5. Gnibidenko G.S. 1979. Tektonika dna okrainnykh morey Dal'nego Vostoka [Tectonics of the floor of the Far East marginal seas]. Moscow: Nauka, 161 p. (In Russ.).

6. Derkachev A.N., Borman G., Graynert Y., Mozherovskiy A.V. 2000. [Authigenic carbonate and barite mineralization in sediments of the Deryugin basin (the Sea of Okhotsk)]. Litologiya i poleznye iskopaemye, 6: 568-585. (In Russ.).

7. Kulinich R.G., Obzhirov A.I. 2003. Barite-carbonate mineralization, methane anomalies and their geophysical fields in the Deryugin Basin (Sea of Okhotsk). Tikhookeanskaya geologiya, 4: 35-40. (In Russ.).

8. Myasnikova G.P., Shpil'man A.V. 2003. [Earth degassing and the formation of oil and gas fields]. Vestnik nedropol'zovatelya Khanty-Mansiyskogo avtonomnogo okruga. (In Russ.).

9. Obzhirov A.I. 1993. Gazogeokhimicheskie polya pridonnogo sloya morey i okeanov [Gas-geochemical fields of the bottom layer of the seas and oceans]. Moscow: Nauka, 139 p. (In Russ.).

10. Obzhirov A.I. Astakhova N.V., Lipkina M.I., Vereshchagina O.F., Mishukova G.I., Sorochinskaya A.V., Yugay I.G. 1999. [Gas-geochemical zoning and mineral association of the floor of the Sea of Okhotsk]. Vladivostok: Dalnauka, 183 p. (In Russ.). 
11. Obzhirov A.I., Sokolova N.L., Telegin Yu.A. 2021. Geological conditions of the formation and destruction of gas hydrates in the Sea of Okhotsk: aspects of tectonics and genesis. Litologiya i poleznye iskopaemye $=$ Lithology and Mineral Resources, 4: 338-348. (In Russ.).

12. Pestrikova N.L. 2008. Polya gazogidratov v Okhotskom more i ikh geoekologicheskoe znachenie [Gas hydrates fields in the Sea of Okhotsk and their geoecological value]: [extended abstract of Cand. Sci. (Geol. and Miner.) dissertation)]. Vladivostok: TOI DVO RAN. (In Russ.).

13. Sakulina T.S., Kalenich A.P., Atakov A.I., Tihonova I.M., Krupnova N.A., Pyzhjanova T.M. 2011. Geological model of the Okhotsk Sea region according to basic profiles 1-OM and 2-DW-M. Razvedka i okhrana nedr, 10: 11-17. (In Russ.).

14. Salomatin A.S., Yusupov V.I. 2009. Acoustic estimate of barite mineralization manifestation in the Sea of Okhotsk. Oceanology, 49(3): 438-441.

15. Kharakhinov V.V. 1998. Tektonika Okhotomorskoy neftegazonosnoy provintsii [Tectonics of the Sea of Okhotsk oil-gas province]: [extended abstract of Dr Sci. (Geol. and Miner.) dissertation)]. Okha-na-Sakhaline: Sakhalin-NIPImorneft'. (In Russ.).

16. Shakirov R.B. 2003. Anomal'nye polya metana v Okhotskom more i ikh svyaz's geologicheskimi strukturami [Anomalous methane fields in the Sea of Okhotsk and their relation to the geological structures]: [extended abstract of Dr Sci. (Geol. and Miner.) dissertation]. Vladivostok: TOI DVO RAN. (In Russ.).

17. Baranov B.V., Karp B.Ya., Wong H.K. 1999. Areas of gas seepage. In: KOMEX Cruise Report I RV Professor Gagarinsky, Cruise 22. Kiel, 45-52. (GEOMAR Report 82 INESSA).

18. Baranov B.V., Dozorova K., Karp B. 2000. Tectonics of the Okhotsk Sea: extension vs compression. In: KOMEX Cruise Report V. RV Professor Gagarinsky, Cruise 26. Kiel: 67-80. (GEOMAR Report 88).

19. Biebow N., Ludmann T., Karp B., Kulinich R. (eds) 2000. Cruise Report 88: KOMEX V and KOMEX VI, R/V Professor Gagarinsky cruise 26 and M/V Marshal Gelovany cruise 1. Kiel, 296 p.

20. Kelley D.S., Baross J.A., Delaney J.R. 2002. Volcanoes, fluids and life at mid-ocean ridge spreading centers. Annu. Rev. Earth Planet. Sci., 30: 385-491. https://doi.org/10.1146/annurev.earth.30.091201.141331

21. Nelson C.H., Thor D.R., Sandstrom M.V., Kvenvolden K.A. 1979. Modern biogenic gas-generated craters (sea-floor "pockmarks") on the Bering Shelf, Alyaska. Geological Society of America Bull., 90(12): 1144-1152. https://doi.org/10.1130/0016-7606(1979)90<1144:mbgcsp>2.0.co;2

22. Suess E. 1999. Fluid venting and barite-carbonate-mineralization in the Derugin Basin. In: Cruise Reports: KOMEX I and II RV Professor Gagarinsky Cruise 22 and RV «Akademik M.A. Lavrentyev». Cruise 28. Kiel, 132-134. (GEOMAR Report 82).

23. Suess E. 2018. Marine Cold Seeps: Background and Recent Advances. In: Hydrocarbons, Oils and Lipids: Diversity, Origin, Chemistry and Fate. Switzerland, 1-21. 